\title{
Assessing Citizen Participation in Public Processes: Making Visible the Ephemera of Decision-Making Talk
}

\section{Diana Wegner}

\begin{abstract}
This paper contributes to current research in communications, rhetoric, and discourse analysis that extends disciplinary interests into the study of citizen participation in public processes. The impetus for this study comes from the troubling consensus that many public decision-making processes tend to discourage authentic citizen participation. In order to investigate the degree to which citizen participation may be judged as authentic, talk analysis is applied to the interactions of a government-citizen group as they negotiate a policy for the management of natural areas.

The investigation examines the interactive dimension of the context of situation, which offers evidence of participation that goes beyond evidence offered by texts alone. The hypothesis is that the contextual dimension of the participatory process should provide richer evidence of the interactive, moment-to-moment, strategic moves of participants. The theoretical framework for the study integrates the concepts of recontextualization and structure-in-action with recent developments in activity theory and theories of agency.

The findings show that, in their meetings, participants agreed and disagreed as they worked toward a consensus on how to write policy clauses. Microanalyses of their talk show evidence of an interactive inclusiveness and meaningful participation that is not apparent in the textual dimension of the written statements the committee ultimately submitted. This method offers researchers in communications and language studies a way of expanding rhetorical analysis to include the interactive dimension of context in real-world processes of civic engagement.
\end{abstract}

Key words: authentic participation, recontextualization, structure-in-action, agency, public processes, decision-making processes

\section{Résumé}

Cet article est une contribution aux recherches actuelles en communication, en rhétorique et en analyse de discours axées sur la participation citoyenne dans les processus publics. La motivation pour cette étude provient de la constatation troublante que plusieurs processus de prise de décision publique tendent à décourager une participation authentique de la part des citoyens. Pour évaluer jusqu'à quel point il est possible de juger la participation citoyenne comme étant authentique, nous appliquons une analyse de discours aux interactions d'un groupe composé de représentants gouvernementaux et de citoyens en train de négocier une politique sur la gestion des espaces naturels. 
Cette approche porte sur la dimension interactive de la situation, offrant une perspective qui dépasse celle provenant de textes seuls. L'hypothèse est que la dimension contextuelle du processus participatif devrait fournir une représentation plus riche des actions stratégiques interactives menées à chaque instant par les participants. Le cadre théorique de cette étude intègre les concepts de recontextualisation et de structure-enaction avec des développements récents en théorie de l'activité et en théorie des interactions.

Les résultats montrent que, pendant leurs réunions, les participants étaient parfois en accord, parfois en désaccord à mesure qu'ils s'avançaient vers un consensus sur la rédaction de clauses. Des microanalyses de leur conversation révèlent une inclusion interactive et une participation significative qui n'apparaissent pas dans la dimension textuelle des écrits que le comité a soumis à la suite de sa rencontre. Cette méthode permet aux chercheurs en communication et en langues d'enrichir l'analyse rhétorique en incluant la dimension interactive dans des processus d'engagement civique réels.

Mots clés: participation authentique, recontextualisation, structure-en-action, interaction, processus publics, processus de prise de décision

Widespread dissatisfaction with conventional processes for public input into environmental decision-making has become, as it should be, an object of study and concern for rhetorical analysis and criticism. Historically, a central concern of rhetorical studies has been the education of a healthy citizenry that can engage meaningfully in public processes. Ideally, citizens should be equipped to strategize with the resources of political and linguistic capital to modify the social, economic, and environmental exigencies of their communities. This expression of citizenship through participation in democratic processes is quintessentially rhetorical. As recent commentary in the Quarterly Journal of Speech (2005) shows, scholars of rhetoric and communication believe they have a professional interest, and obligation, to attend to what they perceive as dysfunctional public processes.

In a 2006 forum, "Rhetoric and Society in the $21^{\text {st }}$ Century," Leff reiterates one of the key questions related to disciplinary relevance: how can rhetoric achieve relevance to the "social, political, and cultural environment" outside the academy (pp. 51-52). In response, Mailloux (2006) proposes that the boundaries between the academy and the "everyday" should become "blurred" (p. 63) and that academic textual analyses should be carried out in the contexts of "public cultural space" (Frow, 2001; as cited in Mailloux, p. 63). In another response, Aune (2006) urges an active role for rhetoric and communications to help redress the deplorable state of current electoral politics: "we have failed to translate our ideals into practical politics" (p. 71). This disciplinary soul-searching is not surprising, given the growing body of research that combines political, sociological, and communication studies for the examination of real-world public processes. One important field that has emerged from this research is environmental communication studies, an approach that extends communication and rhetorical studies beyond the academy into the heart of environmental conflict.

For example, in response to the perceived need to redress the neglected role of communication in public decision-making processes, scholars such as Depoe and Delicath 
(2004) make communications and rhetoric their analytical frame for studying environmental conflict. They expressly aim to "highlight the centrality of communication in matters of public participation in environmental decision making" (p. 3). Their rhetorical definition of communication as "strategic symbolic action shared among people and organizations" and their call for "critical analyses of the persuasive efforts of advocates" (p. 4) fall squarely within the purview of rhetoric and communication studies. Other scholars have also chosen rhetoric and language as the ground for studying public decision-making processes. In an analysis of "instrumental rationality" and the 1979 controversy over the construction and storage of the MX nuclear missile in the Great Basin (Nevada and Utah), Glass (1993) invokes a rhetorical orientation at the outset, asserting that the "basic assumption shaping this work is that democratic political life is fundamentally a matter of argument and conversation" ( $p$. xix). Williams and Matheny (1995) also invoke communication and language as the basis for their Foucauldian analysis of environmental disputes. They examine these disputes as expressions of competing discourses, and propose their own "dialogic model" to address the needs of both citizens and official bodies (p. 7).

The recurring concern of this research is that most public participation is ineffectual: public decision-making processes tend to subvert authentic citizen participation and end up generating a cynicism that further discourages efforts to participate (Depoe \& Delicath, 2004; Herndl \& Brown, 1996; Holland \& Lave, 2001, Killingsworth \& Palmer, 1992; Williams \& Matheny, 1995). Even overt acts of inclusion that draw in public participants can function to disempower individuals through the use of "insidious modes of inclusionary control" (Kothari, 2001, pp. 142-143). Some analysts go so far as to put into question the assumption that public participation is a fundamental good in itself. In the context of participatory processes in development, for example, Cleaver (2001) cites examples of the advantages of nonparticipation and non-compliance (p. 51). The troubling consensus is that traditional forums for public participation are structured and conducted in ways that favour institutional agendas; as a result, the public perception is that it has no voice (Senecah, 2004, p. 19), and the process often stalls out and leads to stalemate (Williams \& Matheny, p. 7). In order to recommend or develop effective models of public participation, we need to provide a shared understanding about what actually constitutes authentic participation and then develop ways of assessing whether it occurs or not in a given public process. Some community organizing models help diverse citizens hear each other and, at the same time, develop a sense of community that honours and contains differences in the interest of common values and goals. When such groups address institutions, however, it is usually difficult to assess the effects of their input.

Tools for assessing citizen involvement in governance are needed to take rhetorical analysis of public participation fully into the contextual dimension of this recurring political situation. Typically, claims about citizen participation tend to be politically motivated and are not easily verifiable. They report either effective democratic processes or citizen co-optation by institutional forces. In the first case, proponents of community involvement promote it as meaningful citizen empowerment; in the second, social critics, often gesturing to a vague, broad political context, condemn it as exploitative or as a form of co-option, usually when community interests have lost out to government imperatives. These competing claims populate much political discourse and commentary. For example, in an overview of the success of "community management" (one term in current use to describe governmental strategies to create community participation), an analyst describes the altruistic goals of 
community management as "personalized services," "stewardship," and "efficient and democratic" processes:

'Community management,' especially of local social services ...

promised highly responsive and personalized services run by people

with direct local knowledge ... the principle which underlay community management was participation. (Darcy, 2002, p. 32)

The same author asserts, however, that the promise of community management has not been fulfilled, for the discourse of management has eclipsed the professed intention of authentic citizen participation: "effectively the ideal of 'community' has been colonized and co-opted by the dominant bureaucratic discourses of the state and the associated practices of public administration" (Darcy, 2002, p. 36). Such highly charged, political claims are not easily verifiable. Often the only evidence of participation is the textual product. Once the interaction has been concluded, it is difficult to test either the charge of co-optation of the ideal or the claim of inclusiveness and participation.

In response to the inadequacy of textual analysis alone for providing evidence of public participation, this study focuses on the contextual, interactive dynamics of participants engaged in decision-making. To investigate this interactive dimension, I have adopted a structure-in-action approach for analyzing the social context that focuses specifically on the dynamics of discursive-rhetorical agency, as they are revealed through microanalyses of decision-making talk. Agency arises out of authentic participation: at the micro-level it is an effect of several layered, sequential strategic and tactical discursive interactions within the general structure of talk. Following Herndl and Licona (2007), agency is explored here, not as individual intentionality, but as "a social/semiotic intersection that offers only a potential for action" (p. 141). It is therefore "constrained": the effect of ephemeral, local, multiply located rhetorical strategies and tactics that broach the modalities of both centre-challenging agency and centre-derived authority (pp. 145-147). My key question is: What can the microanalyses of interactions tell us about human agency in institutional contexts, and citizen participation in environmental decision-making? And, as a corollary, how might a structure-in-action analysis help us evaluate claims and counter-claims about authentic participation and agency?

In the remainder of this section, I propose a working definition of authentic participation and describe talk analysis as a promising method for providing evidence of participation.

\section{Authentic Participation}

For the purposes of this paper, descriptions of authentic participation have been drawn from recent literature on public participation in environmental decision making. These descriptions and terms seem synonymous and roughly equivalent to the concept, "authentic participation." In general terms, it is referred to as "civil discourse" or "responsible public talk" (Daniels \& Walker, 2001, p. 76). More specifically, Walker (2004) differentiates it from mere public involvement: to be meaningful, participation must involve genuine collaboration and must occur as "pre-decisional communication" between official bodies and communities ( $p$. 
115). It must also occur in contexts of sufficient "decision space," that is, where participants have equitable access to power, information, and "participatory decision making" (pp. 119121). Such participation includes ongoing, two-way, face-to-face dialogue and deliberation between citizens and official bodies (Wondolleck \& Yaffe, 2000; as cited in Walker, 2004, p. 123). Authentic participation also requires certain communication competencies of participants: they must know how to be respectful of others' points of view, engage in constructive conflict, tolerate ambiguity, and have a sense of process. The combination of these conditions affords the affiliative ground for building trust-that fragile bond that, according to Senecah (2004), "is overwhelmingly the most commonly identified missing or present element in ineffective or effective processes" of public decision-making (pp. 20-21). Such affiliative ground facilitates the development of "strong citizens," those members of the community who, in face-to-face forums for public debate are pressured to acknowledge and respond to oppositional points of view and to engage beyond rigid reassertions of their own agendas; in this way, they will be able to move towards developing a "sense of the public good" (Barber; as cited in Williams \& Matheny, pp. 197-98). In brief, authentic participation involves collaboration, sufficient decision space, equitable access to power and information, constructive conflict, tolerance of ambiguity, and trust; and, it occurs in pre-decisional, ongoing, face-to-face interactions.

Ideally, a text produced out of authentic participation would make explicit the competing positions of a conflict. It would cite participants' own words, and render the ambiguity and open-ended complexity of such conflict (Schwarze, 2004, p. 155). While this ideal may be worth striving towards, in the absence of such texts, we can seek evidence that people's voices have been heard and that their positions have been attended to through microanalyses of their interactions in the decision-making process itself. Texts are treated here as interactively accomplished accounts, both process and product of transactions between actors who orient their verbal actions to various agendas. Some actions are oriented to noninstitutional agendas, others to institutional priorities: some are centrifugal and have the potential to weaken institutional structures; others are centripetal and re-instantiate institutional structures.

\section{Talk Analysis}

Talk analysis is proposed here as a useful vehicle for making participatory dynamics visible in the genre of policy negotiation. In lieu of real witnesses (see Halloran, 1978, pp. 120 123 for a discussion of the genre of public proceedings and the role of public witnesses), talk analysis can provide some of the missing evidence. The challenge of making the dynamics of participatory processes visible and assessing them for authenticity has recently been taken up as an important task for discourse analysis, specifically where there is an assumption of participatory inclusiveness and consensus in collaborative processes that produce legal and other types of contested texts. For example, in his study of decision-making in meetings in a bureaucratic setting, ledema (1999) points out that, because "the interactional manoeuvring and the power relational struggles are excluded from [the] written version," the textual record "enshrines the consensus as unproblematic, impersonal and durable" (p. 58). The written record elides interactive evidence, "naturalizing the interactional relations and power claims as the 'mere background' against which interactions are played out" (ledema, 1999, p. 58). Similarly, in a study of the "co-construction of a policy paper," Wodak (2000) points to the 
inadequacies of the text to yield evidence of participation that could lead to evaluations of power as shared or as hegemonic: "Are the different ideological and political stances recontextualized into the draft? Does the final version of the policy paper manifest as a consensus or only the opinion which was 'strongest' in the debate?" (p. 79). A method is needed for capturing evidence of the debates, conflicts, and agreements in such processes, for making visible the ephemeral microdynamics of interactions among participants. In their discussion of the same problem, Cook-Gumperz and Messerman (1999) propose that discourse analysis include the study of the "actual face to face discourse of decision making." They point out that "[i]t is at this juncture that we can see an essential tension between the local, situated conduct of working life-its meetings, and any understanding of interactional events on the one hand-and any publicly available written account of these events, on the other hand" (p. 151).

The aim of such analysis is to involve the oral, interactive dimension of context in rhetorical analysis, to "consider semiotic activities as a whole with writing as one constituent of it" (Dias, Freedman, Medway, \& Pare, 1999, p. 35). This contextual approach is consistent with the emphasis in rhetorical genre theory on both form and situation, text and context. It is also consistent with the "discourse" turn in social science methodology and has been widely adopted in recent research that explores the micro-dynamics of medical, bureaucratic, legal and managerial discourses. These studies analyze "talk" either as an object of inquiry itself or as an integral component of text production (Fairclough \& Wodak, 1997; ledema, 1999; Mumby, 1988; Sarangi, 1998; Wodak, 1996). This approach expands the arena of analysis to consider issues of participation, consensus, and the duality of agency and structure. I am proposing that, by rendering decision-making activity visible in this way, we can better assess the degree to which participants have latitude within institutional contexts and, specifically, the degree to which citizens achieve authentic participation and agency in public decision-making processes.

Following Boden's (1994) ethnomethodological approach to talk analysis, this study adopts the techniques of conversation analysis to show how participants use "the mechanisms of social structure . . . in the turn-by-turn development of their interaction, and the way it is, at the same time, the product of that same interaction" (p. 22). Enacted through a "bidirectional connection between social structure and social interaction," talk recursively produces and reproduces social structures across time and space (Boden, 1994, p. 11). Talk analysis can show how such negotiations and agency are constrained and enabled by the structure of talk itself, specifically by the conventions of sequential turn-taking among speakers. Talk is analyzed here for evidence of the interactive micro-dynamics of decision-making to compensate for the fact that "decisions are ... largely invisible and thus empirically unavailable" (Boden, 1994, p. 22). These microdynamics are analyzed as the incremental development of "the fine laminations of actions and reactions that build, from one moment to another" into an agreement at the institutional level (Boden, 1994, p. 22). Boden describes these interactions as "shifting sands of . . . coalitions and cooperations-of-convenience" and offers their analysis as rich evidence of the strategy and creativity that is "lost" once the process comes to an end (p. 193). Microanalyses of talk thus offer in-the-moment evidence of the dynamics of participation that can be examined in a complementary way with other more macro methods of testing for authentic participation (see Senecah's [2004] practical theory for evaluation, p. 13). 
This study examines the interactive dynamics of participants involved in a common type of decision-making process. In this case, a team of municipal staff and members from the community engage in the collaborative development of policy for the management of a city's natural areas. The analysis shows the microdynamics of participants' moves as they engage in this moment-to-moment decision-making process and produce the textual product of policy statements. The design of this study brings text and context into contact with each other through a framework constructed from the concepts of recontextualization (Bakhtin, 1981), activity theory (Dias et al., 1999; Engestrom, 1999a, 1999b, 1995; Lave \& Wenger, 1991; Russell, 2002, 1997; Vygotsky, 1978; Wenger, 1998), and structure-in-action (Boden, 1994; Giddens, 1988; Goffman, 1981, 1969; Schneider, 2007). Using this framework, the study expressly shifts the focus to those sites of recontextualization where the ambiguities and tensions of negotiation arise and are eventually transformed into written language. The ultimate question of participatory inclusiveness is pursued through an examination of text production as a dynamic process of reification and participation (Wenger, 1998), that is, through the mutual processes involving, on the one hand, the reification of prior city texts, bureaucratic rules and procedures, and of managerial constraints, and, on the other hand, participation through the interactions of individuals in the negotiating process.

The findings and analyses show that, over the course of the group's eight meetings, participants agreed and disagreed on how to write and revise policy clauses, and that they generated and sustained cycles of ambiguity until apparent consensus was reached. Although the written statements that the committee ultimately submitted arrived erased of the committee's interactional dynamics, these interactions are made visible through talk analysis. The findings suggest that the closure of the committee's written statements signifies neither co-optation of, nor control by, the community representatives. Instead, microanalyses of participants' talk at these meetings show evidence of an interactive inclusiveness and openness sufficient to support a claim for meaningful, authentic participation. This is evidence that is not apparent in the textual dimension of the rhetorical situation.

In what follows I describe the theoretical framework, methodology, background, and key findings of the study. In the findings and conclusion sections, I focus on the productive possibilities of opening up the contexts of textual production through microanalyses of decision-making talk, and return to the issue of authentic participation and agency.

\section{THEORY}

In this section, the key concepts drawn together for this study are presented and explained in terms of how they have been applied. The theoretical framework includes the concept of recontextualization, activity theory and its related concept, communities of practice, and an alternative view of human agency in institutional contexts, the theory of structure-inaction.

\section{Recontextualization}

In decision-making talk focused on text production, participants recontextualize successive textual drafts and reported speech from prior interactions to mediate their 
deliberations. This process results in those textual statements that will become the official account of the negotiation process. The recontextualization process thus has both a participatory and a textual dimension (Muntigl, 2000). With each recontextualization, participatory tensions are put into play, creating the conditions of possibility for ambiguity, new meanings, and consensus. In this study the business of writing the policy statements began as participants analyzed and responded to a framework for policy statements that the project manager had drafted. This initial framework, which was also a means of managerial control, was received, resisted, and modified through a collaborative process of decision making and text production. As committee members created and responded to proposals for how to modify recontextualized versions of the draft framework, they gradually gave shape to the policy statements.

This process bears some similarity to the process of negotiated policy-making that is the object of Muntigl's (2000) research. In European Union Discourses on Un/employment, he emphasizes the role of recontextualization in both its participatory and its textual dimensions. Policy-making involves both "the institutional, discursive practices used in formulating policy and the outcome of these discursive practices (i.e., the policy)" (p. 23). He explains that "policy process and outcome" are linked "through recontextualizations of the former into the latter" ( $p$. 23). For Muntigl, the main point of analysis is to make visible the ideological concealments that can occur with recontextualization. He emphasizes that "recontextualizations are the sites in which ideological dilemmas can be made salient or non-dilemmatic" (p. 23). The problem, as stated earlier, is that, although textual reifications are available through written drafts, these texts yield few traces of the participatory, contextual dimension of recontextualization. In studies of the production of medical documents, Cook-Gumperz and Messerman (1999) also comment on this problem for the analyst: "the reality is that once the record is created it becomes independent of the particular context of its creation" (p. 146). Wodak (2000) identifies the same problem in her study of the negotiation process and cites the need for analyses that "make the recontextualization process ... transparent, from monologue to dialogue, from written to spoken to written" (p. 93). The analysis of recontextualization should therefore illuminate the ideological struggle that is often erased in the written form.

\section{Activity Theory and Communities of Practice}

The concept of a learning community is adopted to show how the committee's decisionmaking activities actually play out as a combination of participation and reification. This concept has emerged from reconceptualizations of Vygotsky's (1978) activity theory in theories of situated learning (Lave \& Wenger, 2001) and communities of practice (Engestrom, 1999a, 1999b; Wenger, 1998). These theories conceptualize effective workplaces as learning communities that sustain and distribute expertise. They are structured to enable "zones of proximal development" where learners strive to bridge the gap between their learning, which "is in advance of development" and their "learning processes" which need to be caught up to the learning itself (Vygotsky, 1978, pp. 89-90). Through the affordances of shared power, problem-solving space, and tools, such learning is continuous with genuine participation in decision making.

The zone of proximal development is an important analytical concept in studies of agency and team problem-solving in the workplace. For example, in Engestrom's (1999b) 
study of work teams, this zone is a problem-solving space where dialogical tensions can be addressed constructively as participants build alliances, through the sharing of knowledge and the collaborative scaffolding of ideas. Two key conditions for the success of such processes are a bonafide "decision-making space" that allows for a sharing of decision-making power among participants (Walker, 2004, p. 119) and shared availability of relevant tools and information. In a learning community, meaningful participation is dependent on this shared power-space and the reification and recontextualization of tools and information. Wenger (1998) describes the dynamics of such learning communities as fuelled by the interactive duality of participation and reification (pp. 51-71). Participation guarantees that reified forms will be recontextualized as they are taken up by participants, ensuring that "[t]heir meaningfulness is always potentially expanded and potentially lost ... incomplete, [and] ongoing" (Wenger, 1998, p. 62). In order to proceed, on the other hand, participants, in turn, must use and reify "artifacts, words, and concepts" (Wenger, 1998, p. 67). Together, reification and participation create the conditions for renegotiations of meaning which Wenger describes as "transformations - the production of a new context of both participation and reification" ( $p$. 68). I have borrowed this elaboration of learning community and participation into the municipal context of this study where "work" is similarly accomplished by the policy committee. This paper follows their activity through recontextualizations and transformations of a key element of the city's natural areas policy: language on land acquisition.

\section{Structure-in-Action: Agency and Institutions}

The expressed agenda of theories of structure-in-action is to articulate how institutional power operates, not as hegemony, but as an interactively accomplished activity, and to thereby make visible the dynamics of negotiated structure, as opposed to describing the static features of structure once it has been accomplished (Boden, 1994, p. 4). According to Boden (1994), instead of focusing on how participants "respond to normative constraints," a structurein-action approach examines how "such microscopic events as turns at talk embed and enact . .. institutions" (p. 11). Such analysis allows the tracking of the incremental, sequential nature of the accomplishment of decision making and organizational agendas (p. 17-21). As Goffman $(1969,1981)$ and others have proposed, organizational rules are not rigid and stable; instead there is a "loose coupling" of rules and the following of rules (Boden, 1994, p. 154; Giddens, 1988, p. 272). Rules are "worked out on the spot" (Boden, 1994, p. 193) and are "subject to human agency" (Boden, 1994, p. 205). Microanalyses of face-to-face talk bracket the micromacro duality of institutional structure in favour of a more integrated analysis of the embeddedness of structure and power in talk itself. Talk analysis is thus performed in order to reveal how participants "discover from within the local logic of their actions" and how a sequence of events comes to constitute both decisions and institutions (Boden, 1994, p. 198). It shows the linkage between "immediate reasoning" and "relevant institutional rationalities" (Boden, 1994, p. 180). As decision-making talk proceeds, the long-range goals of the discourses and institutions toward which participants are oriented are sequentially accomplished. Institution is embedded in the individual and the individual in the institution. From moment to moment, unique interactions weaken, then strengthen institutional structures; over time, these interactions will re-instantiate or transform the institution. 
Analyses of decision-making talk that use this interactive approach to structure are based on the premise, as framed by Boden (1994), that by "[l] ooking at language-in-action, we get a direct view of human agency" (p. 57). Decision-making talk is framed by both institutional structures and the sequential structure of talk itself. Even as talk reproduces structure, its sequential nature affords opportunities for human strategy and agency. These opportunities can also exploit the affiliative ground that develops through ongoing, face-to-face verbal interaction. A kind of "cooperative confidence" (Boden, 1994, p. 22) develops in talk as "each speaker tracks the other, correcting, agreeing, adjusting, and collaborating at each stage" (Boden, 1994, p. 61). Participants become interdependent as they come to function as "sources of information for one another" and as they come to trust and accept each other's turns on trust (Kendon, 1988, p. 22). And, although every case of co-present interaction is potentially confrontational, individuals also work to maintain respect and consideration for each other and to prevent face-threatening acts. In contexts where repeated interactions occur, as in a series of meetings, this bond tends to deepen, growing from the initial "relationship wedge" (Goffman, 1963; as cited in Giddens, p. 264) into a sense of commitment and trust that each speaker will provide suitable responses compatible with their strategic uses of the ritual of turntaking.

On this ground of trust, then, speakers use the very constraint of sequentiality itself as a strategy for changing topic, interrupting, and re-orienting their position. Each action involves taking, re-taking, or changing one's position and is subject to a range of immediate responses from the next turn-taker/turn-maker, resulting in a fluctuating series of alliances, coalitions, ambushes, and conflict (Boden, 1994, p. 102). This ongoing positioning, Boden (1994) explains, is not just "some side-show to the "big decision," but "turns out to create the fine threads through which the web of opinions, options, angles, alternatives, and occasional actions of 'decision-making' are woven" (p. 87). Speakers thereby strategize their moves in favour of their own agendas and, at the same time, attend to and use the socially cohesive moral force of trust that turn-taking fosters. Through the ongoing interactions of decisionmaking talk, participants, gradually and incrementally collaborate towards what will later be named a "decision." Over successive meetings, the laminating effect of ongoing interactions builds the basis for subsequent interactions that will later produce decisions. As Boden argues, "Organizational decisions are talked into being"; only "retrospectively" do they "look like decisions" (p. 91). This participatory dimension of decision-making, as evidence of a constrained agency, is the object of analysis in this paper.

\section{METHOD}

The study covers one year-long phase of a larger, long-term project to manage a municipality's natural areas. This particular phase involves the initiation and completion of the development of policy for natural areas. It begins with the convening of a policy committee by a city manager in 2002, follows the committee through all of its eight meetings, and ends with their last meeting in 2003 and the product of their decision-making, a set of policy statements.

The methodology is based on a participant-observer relationship with committee members and on qualitative methods of data collection. The participant-observer stance was facilitated by the author's association with a number of citizens involved in the project, ongoing 
membership with one of the city's environmentalist groups, and past consulting work for the parks department. This relationship provided the ground for the generation and collection of both contextual and textual data. Methods of data collection included written observations at eight meetings (seven of them taped and transcribed), participant questionnaires, and a focus group interview with committee participants (taped). Transcriptions of verbalized discourse were analyzed for the interactive dynamics of decision making as participants negotiated the policy statements. A simplified approach to transcription has been adopted and the finer transcribing of phonological phenomena has not been included. A number of relevant texts were also examined, including city documents (notes, minutes, correspondence and foundation documents), draft versions of the policy (including the initial framework, subsequent drafts and rewrites), and the final written policy. The primary research site was the parks and recreation department's meeting room. Data selected for analysis pertain to one particular key issue of negotiation, the inclusion of a policy statement on land acquisition.

\section{BACKGROUND}

\section{The Historical Context}

A history of innovation brought the municipality's overarching natural areas management project to the phase of creating the policy committee. Over a period of approximately ten years, the philosophy and direction of the parks department gradually moved from individual tree care to concerns about the city's urban forests, and ultimately about all of its remaining natural areas. The phase of the project that is the subject of this paper occurred subsequent to the development of the natural areas management plan. It began with the creation of the committee and ended with its disbanding after the last meeting (2002-2003).

When the management plan was created in 2001, specific language for a land acquisition strategy was considered important but politically problematic. As a result, it became black-boxed as an issue to be addressed outside the plan, possibly at the policy stage. The management plan contained only a few references to "land acquisition" and these were expressed in relatively weak language. Nowhere does the plan address specifics, a process or the assignment of responsibility for land acquisition. It should be noted that community members (whose feedback had been requested) expressed concern that the management plan had not adequately addressed the issue of rapid development of natural areas in the city and the need for a land acquisition strategy that would stipulate additions to existing natural areas. Upon completion of the management plan in 2001, both the project manager and senior parks manager expressed the hope that the subsequent development of natural areas policy would include land provision standards.

In order to develop an initial framework for writing policy, the project manager excerpted parts of the plan's overview, summarizing, paraphrasing, and copying verbatim key initiatives. He incorporated part of the "biodiversity" principle from the plan: "The following general recommendations support the theme of biodiversity conservation," but he omitted the "acquisition" part of the principle: "to acquire a wide variety of natural areas . . representative of the diverse habitats within the City" (Natural Areas Management Plan, 2001, p. 20). Similarly, he incorporated part of the "fauna management" principle, omitting the goal to 
"acquire a wide range of faunal habitats that promote the principle of biodiversity" (p. 24). While participants were encouraged to read and refer to the plan itself, this shorter framework was the text that became immediately available to policy committee members. It became the mediating focus that put their different interests into play and propelled their discussions. The language of the framework acted as a centripetal base, a provisional agenda set by the project manager. As it became activated, however, participants recontextualized its statements in their deliberations, modifying and making additions that reflected their interests. Specifically, conflict developed between the project manager and other committee members over the inclusion of land provision standards. This conflict drove a series of verbal and written recontextualizations and transformations as some elements from the original framework were reified and others added or deleted. Each draft and each meeting reset the decision-making context and became another occasion for the interactive process of proposal, response, and evaluation.

It should be emphasized that the rapid development of natural areas in the city had ongoingly and increasingly become a source of community anxiety and protest. Most of the community members on the policy committee were already environmental activists involved in stewardship projects and anti-development presentations at city hall. (This issue became a flash point in the municipal elections of 2005 when the incumbent mayor was voted out and replaced by a new mayor who had largely campaigned with a platform favouring "good development.")

\section{The Committee Members}

Most participants on the policy committee attended all eight meetings. Of the nine members, one was the project manager (PM), two were politically appointed parks commissioners (COMs), and six were community members (CMs) selected by the project manager for their involvement in environmental-related groups and city projects. About half of them had had some involvement in providing feedback to the earlier management plan. The PM describes himself as a "nature lover" and "administrator." One COM chairs a subcommittee of the parks division; the other has served on the outdoor sports advisory committee for the city and has been involved with the Boy Scouts. Of the six CMs, two are presidents of parks advisory committees and have been active in several city projects involving environmental protection. The other four are active in various environmentalist contexts as members of fish habitat rehabilitation groups, the local chapter of the Western Canada Wilderness Committee, and local naturalist organizations.

\section{RESULTS AND DISCUSSION}

The findings show that throughout the decision-making process there was a certain "play" in the conflict between the PM's recurring references to institutional constraints on policy "scope" and participants' concerns to protect and acquire more natural land. The forces involved in this conflict do not seem to manifest as polarities but instead foster a kind of ambiguity and create a space for learning, questioning, and deferring big conclusions. The findings fall into three categories: the manager's role as a broker, relevant textual 
transformations, and the relationship between textual changes and the decision-making process.

\section{The Project Manager: Institutional Representative and Broker}

In commenting on meetings used to create medical records, Sarangi and Roberts (1999) point out that, "In many respects, meetings are hybrid speech events which position participants hierarchically" (p. 72). As a result, participants "have to mediate between what is in the best interest" of their "clients" and "what the regulating bodies require as documentary evidence" (Wenger, 1998, p. 105). The PM takes a proactive lead in managing this mediation. He often intervenes with administrative concerns, but he also operates very much in the role that Wenger (1998) defines as a "broker," someone who can provide "connections" (p. 105) between two communities, by "introduc[ing] elements of one practice into another" (p. 109). In this role, the PM reifies, over a sequence of turns and meetings, certain organizational agendas, yet also engages in certain responses and position-taking that cedes important decision-making space for participants. As the broker located at the boundaries of these communities, he can exercise both authority and agency. On the one hand, he can introduce committee members to the city's internal administrative practices for developing policy. On the other hand, he can also help open up spaces for citizens to speak, by offering responses and taking positions that afford others important decision-making space. In this role, as a change agent, the PM can "enable coordination, and ... open new possibilities of meaning" (Wenger, 1998, p. 109).

Obviously, as the primary institutional representative at these meetings, the PM is not a disinterested facilitator. As Agar's (1985) work on institutional discourse would predict, his participation is often motivated towards "institutional discourse control," especially in the face of institutional forces that are beyond his influence (p. 156), such as deadlines, budgets, and politics. This aspect of the PM's role is similar to that of the team leader in Cook-Gumperz and Messerman's (1999) study of collaborative record construction. As that committee drafted policy statements, a manager "monitored" others' proposals for written language and periodically invoked institutional "rules" (Cook-Gumperz \& Messerman, 1999, p. 166). The challenge for managers is to balance this institutional responsibility with a responsibility to engage participants in authentic decision-making. As the PM takes the lead in interpreting, privileging, and setting certain topics and boundaries for discussion, he must also accord participants sufficient decision-making space and demonstrate that he shares the same larger goal of their task. Although he can initially assume some trust in his brokering based on social and political capital acquired prior to the policy making process, he must also sustain sufficient decision space for others. As a representative of the "decision authority," he must also share the power of actual decision-making (Walker, 2004, p. 119). In other words, his agency can allow openings for the agency of more peripheral participants and the creation of the conditions of possibility for change.

How the PM manages this challenge is illustrated in the following series of exchanges at the second meeting. He intervenes to define and redefine the official scope of the committee's mandate, but he also hedges his interventions and invokes common ground with participants in an effort to balance his brokering roles. In the first exchange, for example, he becomes 
alarmed by a community member's reference to the "entire city" as a "natural area" (1), for such scope suggests the inclusion of private natural areas over which the parks department has no jurisdiction. He is particularly motivated to block such efforts to include language regarding the acquisition of any such "private" natural areas, and so reminds the committee that these lands are not within the committee's purview (2). In this response, the PM asserts this institutional "rule" with an expression that upgrades his stance towards confrontation: "don't forget . . It's not about . . . private land ... this is strictly confined to park natural areas," but he also downgrades this confrontational stance, hedging it with conciliatory language, "as much as l'd like to talk about that," and tagging it with "OK?" to suggest agreement. He then appeals to the group's common ground, alluding to their larger goal to steward natural areas: "because everybody's interests is there." The rule thus becomes expressed through a position that is both firm and conciliatory. Having broken the conversational frame to re-key the discussion on rule observation, the PM invokes common ground as an invitation to return to the business of the committee. Members register assent (3) and change the topic to "tree counts" (4):

(1) CM1: ". . in addition to these very specific things that [the PM] has pointed out, these specific areas that are including natural areas, there should be a basic feeling or a basic premise of, of governance of the city, should be, the entire city's a natural area, and you should do whatever possible to keep it as natural as possible..."

(2) PM: “. . . don't forget that's what this is about. It's not about needing trees and private land or boulevard tree planting, etc. As much as l'd like to talk about that, ... this is strictly confined to park natural areas, ok? And, and, uh, the only reason I say this is, scope . . . very easy in this group to do that [i.e. exceed the scope of the policy], because everybody's interests is there."

(3) CM2: "Yeah."

(4) CM3: "Ah, I think I was going to bring up ... something about, um, you know, overall removal of the trees and ... that you need a reference point to start with ... how many trees there are in [the city] overall ... Who knows?

In the next exchange, we see how members return to both the issue of private lands and the status of non-parks natural areas that the city owns. In response, the PM revisits this tendency of the committee to go beyond the parks' natural areas and to exceed the scope that he has tried to maintain. These exchanges usually occur in relation to proposals by community members for a clause on land acquisition. For example, at the fourth meeting (September 23, 2002), during a discussion of a possible clause on advocacy, when a member (CM2) suggests adding language to protect natural areas overall from development (6), the PM orients his response to the institution, reminding members that the committee has no power to divide up "natural areas" that are not "parks" (7). He reasserts the "scope" rule indirectly ("this is not a committee that's going to have any ... influence on how this city is divided up in terms of ... natural areas"), implying that private lands are off-limits in their deliberations, and that other city documents would override the committee's statements. This could be a downgrading of the scope rule, from direct rule assertion to indirect rule inference. The PM then asks an apparently tangential question about previous "meetings" held for public input, steering away 
from the rule intervention, keeping channels open and attenuating the discussion. The next turn is inaudible and short (8), suggesting that committee members are ceding the floor to the $\mathrm{PM}$, and letting him answer his own question. In apparent agreement, CM1 then returns to the topic of composing an advocacy clause (10):

(5) CM1: ". . focusing on the advocacy issue now, who's advocating for the land and whether it should be something in here that sort of ..."

(6) CM2: “. . there seems to be somewhere some, ah, serious elements missing ... maybe what we start to talk about is, what is it that makes the city ... different from anywhere else? And if those things are really important, then we see to it that those [non-parks natural areas] are protected and preserved, and with everything else, that's where we develop."

(7) PM: "Well, you know, again, you're talking pretty global, and l've got to caution you on that because this is not, um, a committee that's going to have any, any influence on how this city is divided up in terms of commercial and residential natural areas, what's left, etc. when you hit that acquisition [a proposed clause on land acquisition], you have to hear what I'm talking about, you'll have a clear idea of the role that we play and how this policy might affect some of that ... this has been the theme of this committee, is to expand beyond the borders of park natural areas ... you won't be able to influence ... what is already in a future [city] vision document. Those are done ... was just reviewed. Did anybody hear about any of the meetings?"

(8) 0 [Inaudible]

(9) PM: "It was in the papers . . those are the opportunities to do that, I'm afraid it's not here ... overriding documents ... are already out there in the planning process."

(10) M1: "It just seems to me that this would tie into advocacy . . . maybe ... work out . . . a nice general statement of advocacy?

Towards the end of the fourth meeting, in a discussion of "buffer zones," when a member raises the issue of a land acquisition clause again (14), the PM responds to this recontextualization initially by suggesting the inclusion of "a general statement" about buffers (eliding any reference to land acquisition) (15). However, he seems to soften his concern about scope, recontextualizing the proposal for an actual clause on land "acquisition" ("under acquisition"), which he has yet to support in itself, as a possible strategy to address acquiring buffer areas (to prevent encroachments on natural areas) from non-parks lands (17). Collaborating then with the PM, another member builds on earlier remarks by the PM and proposes a separate acquisition clause (18). In response, the PM implies agreement ("Pair it up.") (19); the CM also agrees ("Yeah.") (20). In this exchange, using his power as agent, the PM allows members the decision space to possibly modify the scope rule:

(11) CM1: Does it have to be just public land? Can't we be encouraging —-the whole city planet as well to add buffers?

(12) PM: "This is park natural area- 
(13) CM1: "I know () really close to that () and got over it/"

(14) CM2: "() land acquisition ()"

(15) PM: "You know buffers are good for the natural areas ... whether that buffer be on private land or public land or whatever, it's just better for a natural area to have a buffer ... make that, you know, general statement."

(16) CM3: [inaudible]

(17) PM: "You could, you know ... acquisition, once you hear about acquisition, you might come up with a bunch of stuff ... providing buffers around certain places natural vegetation for, you know, leaving the connections for wildlife, etc., yeah."

(18) CM3: "Based on what you said earlier . . I I think it would be best dealt with under acquisitions as a separate item under acquisitions."

(19) PM: "Pair it up."

(20) CM3: "Yeah."

A certain ambivalence seems to develop out of the latitude in decision-making space that the PM has tacitly allowed for shifting his position on the scope rule, and out of the sequential process that imbeds the land acquisition agenda to which other participants keep returning. This recursive movement between the poles of disagreement and agreement, and the negotiated modifications that are constructed along the way, contribute to an ambiguity and open-endedness that come to characterize negotiation over the "land acquisition" clause overall. The important ground for this process is the decision-making space that the manager allows and that is, itself, also an effect of the decision-making process wherein decisions are interactionally accomplished. The process leaves open opportunities for pursuing one's agenda through a change in footing. Following Goffman (1981), this change entails a "transplantation of a participation framework" (p. 155) that can work towards agreement or disagreement. As the PM's brokering fosters wider distributions of agency and tactical positionings, transplantations can accumulate toward structural change.

In the next subsection I track the textual transformations that occurred in the policy statements, and then examine the changes in the drafts of policy language within the context of the group's extended decision-making process.

\section{The Textual Transformations}

A comparison of the PM's framework document and the final version of policy statements shows the key textual changes that occurred as a result of the committee's deliberations. The PM's initial written framework for policy language included sections on the purpose of the policy, the purpose and definition of natural areas, a vision statement, and two sections comprising 17 principles. In the final form of the policy document, the language and intent of many initial clauses were revised: the vision statement was rewritten and moved to the beginning, and significant new principles were added for a total of 21 instead of 17 clauses. 
Participants developed and debated a series of recontextualizations that ultimately resulted in a few but significant textual transformations. In order to categorize these changes, I have borrowed Wodak's (1996) taxonomy of four types of "transformations" that result from recontextualization (a concept adapted from textlinguistics): addition, deletion, rearrangement, and substitution of elements (p. 10). Of these, the two key transformations that occurred during the decision-making and drafting process were addition and rearrangement. Two clauses were added, one on the creation of a community advocacy group for natural areas and the other on land acquisition; and the land acquisition clause was eventually moved from a position towards the end of the document to an early position of greater priority. This analysis focuses on the interactive moves involved in re-appearances of the land acquisition issue, which became an intense object of negotiation, and its eventual addition to the policy as an explicit statement of intent.

An overview of the development of the relevant textual transformations is as follows. At the first meeting, community participants and parks commissioners introduced "parkland acquisition" as a topic to be added to the PM's framework. At the second meeting committee members discussed the topic in terms of "land provisions," and at the third meeting, one of the community members proposed language on an "Acquisition" policy statement. Discussion of this clause was deferred at the fourth meeting by the PM who wanted the committee to hear from the overall manager of the parks division himself to clarify what powers the parks division did and did not have over land acquisition. At the fifth meeting the parks manager presented this information for committee members. At the sixth meeting language for the "Acquisition" section was negotiated and more or less finalized.

\section{The Microdynamics of Decision-Making: Conflict, Ambiguity and Consensus}

This section analyzes how participants pursue agendas that conflicted with the PM's institutional agendas, and how they argue and collaborate with each other, positioning their own agendas in recontextualizations of written and spoken language for a "land acquisition" clause. Through sequential exchanges and over the course of the eight meetings, the group engaged in decision making as a dance of agreement and disagreement, incrementally scoring small wins and incurring small losses. These exchanges provide a picture of participants' interactive, strategic uses of the order of talk itself, and of the resources offered by recontextualization. They include conflicts, the development of ambiguity, and provisional achievements of consensus and closure. By exploiting the sequential structure of talk through the insertion and re-insertion of contending agendas, participants fostered a modicum of openendedness in their deliberations. This decision-making space — what Menz (1999) describes as a "metastable communicative space" (p. 123) —and process facilitated ongoing discussion, deferring closure and creating a certain ambiguity, first around the possibility of including such a clause, then around what questions it should address, and, finally, how it should be worded. This ambiguity and open-endedness in participants' deliberations has the effect of attenuating the discussion, deferring closure and sometimes leading to genuine consensus. As Menz points out, "ambiguities do not have to be resolved on the spot but can be kept open over longer periods of time thus ensuring the availability of a greater range of solutions to problems" (p. 106). Notably, members of the committee seem to be disposed towards a tolerance of ambiguity - a key feature of an effective learning community, and one index of authentic 
participation. Through a series of exchanges over meetings participants thus come to construct and endorse a negotiated compromise. This analysis helps make visible the ephemera of their in-the-moment, face-to-face interactions, and provides a basis for evaluating the authenticity of their participation.

In what follows I analyze two cycles of activity over the course of four meetings to show how participants problem-solve the question of a land acquisition clause. The first cycle revolves around the issue of maps, which function as key sources of information in the decision-making process. Participants regard the maps as necessary to provide evidence of the need for an inventory of natural areas (the first cycle of activity). The second cycle of activity revolves around using the proposed inventory as a necessary preliminary determination towards composing a language acquisition clause for the policy.

\section{Cycle 1: Sharing Information}

Beginning with the second meeting (June 3, 2002), members repeatedly express their desire to see a map that shows all the city's natural areas, public and private ("the map ... is so important" [21]), with the as-yet-unarticulated intention of specifying how much natural area should be acquired and stipulated in the policy. The PM's response is oriented to an institutional perspective on policy writing, disallowing space for making changes. He reiterates a version of the scope rule, emphasizing that writing policy involves "value statements," not "specifications" for amounts ("how much") of natural areas land (22). He presents this as a forceful, non-modalized stipulation: "you aren't doing/you're doing" (22).

(21) COM: "The reason I think the map [of all the city's natural areas] is so important is because to protect the natural areas we have to know how to transition from a natural area to a passive park or a development ... "

(22) PM: "You have to help me understand why you need to know where and how much. To put a value statement, remember, this is about a value statement, it's not about specification. You guys aren't doing specifications, you're doing value statements. That's what policy is. I'm not sure why you need to know so many specifics to make value statements."

As the discussion continues, members keep pressing for specific language on acquisition, and return to their desire to examine maps as a guide. At one point, the PM proposes a compromise, reformulating his earlier stipulation that the committee restrict itself to "value statements." Here, he suggests ("you could") that they include a "value statement" "about acquisition" that would state "park natural areas are . . important" (without mentioning "how much" land should be acquired) (23). At first, the chair makes supporting sounds ("yeah") (24). However, when the PM declares point-blank that committee members will not get the language they want ("you are never going to satisfy your need to know how much" [25]), citing city constraints ("nobody in the city would be able to do that"), the chair returns to "the need for a map" to "see where the natural areas are"(28), a subgoal towards his agenda to establish and then specify in a policy clause how much natural areas should be protected or acquired. The chair argues that a map is necessary to know where to connect natural areas. The PM finally agrees, under some duress, to look at the maps, "OK, let's go. I'm losing patience" (29), a development the Chair apparently approves: "That got some action" (30). Although he is 
clearly frustrated, the PM concedes to the group's agenda to look at a map in order to assess "how much" natural areas should be protected. In sharing this institutional source of information as a key problem-solving tool, the PM orients his response to the group's priority, allowing some decision space toward the possibility of change. The chair, in turn, can exercise some agency and take up a position for maneuvering toward the subsequent tactical move to include a land acquisition clause in the policy:

(23) PM: “. . under number 9, page 4, "Planning and Development," you know, this is where you could put in a value statement of some kind-it's very general, but, in fact, about acquisition and division . . . but I mean there could be a bullet put in here saying, you know, park natural areas are as important as everything else."

(24) Chair: "Yeah."

(25) PM: "Well, I mean something like, may be enough. You are never going to satisfy your need to know how much . . because nobody in the city, including myself, would be able to do that in the space of this time here."

(26) Chair: "() from a policy point of view ()"

(27) CM1: [inaudible]

(28) Chair: ". . I l just wanted to mention something about, you know, getting back to this map thing. The need for a map showing natural areas. Um, I think, ah, I mean, in the last meeting we talked about, you know, wildlife quarters, you know, the importance of connecting natural areas, um. It seems to me that a map, you know, if you can see it laid out on a map, you can, ah, see where the natural areas are..."

(29) PM: "OK, let's go. I'm losing patience ... but let's go, let's go look at some maps right over here. Guys, come one. This is the only way I can do this."

(30) Chair: "That got some action."

In agreeing to look at the maps, the PM adds some tacit weight to the importance of knowing "how much" natural areas exist, which is a first step many participants see as necessary for writing policy on land acquisition. Participants study the maps on the wall and then resume their discussion. In response to one member's proposal to "say something such as ... natural areas have equal value to the developed parks" (31), the PM now seems more disposed to including "some statements in there ... providing even more of this stuff" (32). Downgrading his own agenda, the manager allows that "to put something in there" is "quite within [the committee's] means" and "within [their] right as a community" (32). On the other hand, he speaks of it conditionally ("if this group decides," "if you guys put in something," "whether it gets through," "even if"), though with some permissive modality ("you might want"). Then, upgrading and orienting his response to the institution, he adds that his "boss and the planning manager will have to take a look" at it, indicating that it might not get "through to the parks commission." He refers to such potential policy statements, somewhat trivially, as "stuff" and advises deferral for now (32). This double-voicedness creates ambiguity and the conditions of possibility for more shared agency and change: 
(31) CM1: "With regards to the planning and development of number 9 that we could say ... that natural areas have equal value to the developed parks?"

(32) PM: "Well, um, I was just trying to get us over that hump of thinking strictly about provision and protection of, of a land base that hasn't been developed yet ... However, if this group decides to put something in there ... when you get there, when you get to that point. And the reason I say when you get to that point is because I see this discussion ... so far pretty loose. ... When you get to "planning and development," you might want to ... some statements in there because you obviously all care about, um, providing even more of this stuff, and, um, that's quite within your means to do that, and within your right as a community to do that. Um, whether it gets through to the parks ... commission, it's hard to say. Ah, if you guys put in something that's way out there, um, my boss and the planning manager will have to take a look at the whole thing ... My advice to you is start working your way through, you know, start even if-you know, 1,2 , eventually put stuff in there."

In this long response, typical of managers at meetings, the PM's concession, couched in conditional language, creates an ambiguity that leaves the possibility for re-openings and extensions of the decision-making process. He orients to the institution's priorities, but he has changed his footing with the other participants through the sharing of decision space.

\section{Cycle 2: Negotiating a Policy Clause}

At the third meeting, the inclusion of language on acquisition in the "Preservation and Protection" clause becomes a bona fide initiative. Working with language from the draft framework, one community member (CM5 below, who is absent from this meeting) has drafted a clause that contains some significant changes. The original wording in the draft framework under "Preservation and Protection" was as follows: "Natural areas need preserving and protecting to meet the needs of the present without compromising the needs of the future." In the new clause, the word "acquisition" is added to the heading to read "Acquisition, Preservation, and Protection," and the scope of the policy is expanded to include both "public" and "private lands":

Natural areas must be preserved and protected to meet the needs of the future without compromising the needs of the present. Whenever and wherever possible, natural areas worthy of preservation and protection should be identified, whether in existing public lands or in private lands that may become developed and partially transferred to the public for park expansion. (June 8, 2002)

The following excerpt shows that the rest of the committee approves of the language, for it serves their goal to include a land acquisition clause: they "like" it $(34,39)$; it's "nice" (40); it's "for the needs of the future" $(41,52)$; "[CM5] has added the word acquisition" $(47,51)$ :

(33) Chair: "OK, guiding principles. Shall we start with, um, [CM5's] suggestion about acquisition? 
(34) CM1: "I just had a note that I really liked the third bullet. Where it says 'without compromising the sustainability of natural areas'."

(35) CM2: "Right, yeah."

(36) CM3: "Yeah."

(37) Chair: "Oh, I see. He's twisted it around a bit, eh?

(38) CM2: "Oh, he has."

(39) CM3: "Yeah, I like the way he's done that."

(40) CM1: "Oh, nice, yes I see."

(41) Chair: "That's basically what you're doing it for. You're doing it for the needs of the future."

(42) CM1: "Future, yeah."

(43) CM4: "What are you referring to?"

(44) Chair: "Acquisition."

(45) CM1: "This is number two."

(46) Chair: "His_-"

(47) CM1: "[CM5] has added the word acquisition-"

(48) Chair: "O you know 0"

(49) CM4: "Ok. Are you looking at the acquisition one?"

(50) Chair: "Yeah."

(51) CM1: "Yeah, he's put acquisition in front of preservation and protection."

(52) Chair: "And, then, he said he wants to um, natural areas must be preserved in order to meet the needs of the future, not the needs of the present."

After a few minutes of general, reinforcement talk the PM falls into apparent agreement with the committee's proposal for a land acquisition clause, saying, "So natural areas must be preserved, protected, and strategies identified to meet the needs of the future and present" (52). One member then proposes a revision, "must be preserved, protected, and acquired" (55). The PM's comments illustrate the double orientation of his brokering role. On the one hand, it is responsive to members' environmental priorities in that he suggests that acquisition should have a clause of its own: "I think acquisition should be a different ... heading ... before preservation and protection" (56). On the other hand, it is also oriented to institutional constraints that he knows do not empower the committee to include language on "acquisition." His suggestion is embedded in traces of this institutional orientation manifested in tentative language, with weakly modalized verbs, "I think" (56) and "it could be" (60), and a major 
qualification, "This one will be difficult" (62). He makes these comments in discussion with the others, as follows:

(53) PM: "So, natural areas must be preserved, protected, and strategies identified to meet the needs of future and present?"

(54) CM4: "For—um, yeah, I guess so, something like that. Should be 'must be' preserved and protected."

(55) CM1: "We need to put this into perspective. We need in that sentence to incorporate the three words that govern. So natural areas must be preserved, protected, and acquired."

(56) PM: [inputting into his laptop]: “What I'm doing here, I don't know if you guys will accept this, but I think acquisition should be a different, um, heading ... it should probably, before preservation and protection, . . . but I think you talk an awful lot add 0 about acquisition, about, and how we've addressed that, but you still wanted to

(57) CM4: "Oh, OK.

(58) PM: "Um, more acquisition. So, um, with respect to your sentence there-_"

(59) CM1: "OK, then, have its own section?"

(60) PM: "It could be." ... .

(61) CM4: "But, ah, yeah, I agree, that it has to be, it shouldn't be buried in that section-so if we have preservation and protection, and, say natural areas must be preserved and protected to meet the needs of the present and the future, period. Then we may have, the next title is acquisition-whenever and wherever possible, natural areas worthy of preservation and protection should be identified-and acquired when they're in existing public lands or private lands that may become developed and partially $0 "$

(62) PM: "This one will be very difficult."

Committee members agree with the PM's suggestion to make "Acquisition" its own clause. Momentarily, the PM seems to have accepted the inclusion of a clause on acquisition. However, later in the same meeting, under the pressure of the two conflicting orientations, he reassigns the "acquisition strategy" clause, from its status as possible language in the policy draft, to a dubious existence outside of the policy document. Returning to the "scope" rule-to exclude issues of land acquisition from the policy-he suggests that language on land acquisition be conveyed as a need, not in the policy, but as "a strong recommendation" in an oral preamble as part of the actual presentation of the policy to the parks commission $(63,65)$. $\mathrm{He}$ orients this response to the city, to its pro-development history, and its currently intense political climate. As in the prior management plan, "acquisition" would again be black-boxed and removed from the policy because of the difficult reception it might receive. Again, the gesture is to reify it in a less formal, less visible, and therefore weaker form (the oral preamble) 
as a task to be completed at an undetermined time in the future. Returning to the environmental agenda, the chair expresses disagreement with this suggestion, and counters with fairly strong obligatory modality, that an acquisition strategy "should be" in the policy (64). The PM responds with a now hedged, re-assertion of the scope rule: "I'm not sure if you can say that on policy" (65), and exerts strong obligation on the committee to comply, "it wouldn't be in the policy/it would be in [a preamble]"(65).

(63) PM: “ . . probably possible that a person from here could actually do the presentation [to Commission] or, um, something needs to be written up ... [such as] this committee is concerned about, ah, if there is a lack of an acquisition strategy that there should be one. And it could be one directed at the issues other than the policy. There should be an acquisition strategy that is developed in the next couple of years for the natural areas."

(64) Chair: "You know what should be even better is that there should be acquisition strategy [in the policy]."

(65) PM: "I'm not sure if you can say that on policy, if you look under policy, but, this committee can be, I think this was discussed, could very easily have that as a strong recommendation. It wouldn't be in the policy, it would be in [a preamble], here's the policy, we think it's good, but here's what's lacking . .."

After a number of such exchanges, the discussion reaches temporary closure with the PM's suggestion that they hold off on "acquisition" language until the senior manager visits at the next meeting (67). A member approves of this proposal (68), and, as the PM re-engages, he seems re-inclined to consider the inclusion of an acquisition clause ("talk about acquisition strategies") (69):

(67) PM: "I think you guys should . . . hold those things until after we hear from [a senior manager], OK? ... I think you guys are always going to keep the steam alive to the very end. And l'll get the next meeting...

(68) CM1: "That'd be good."

(69) PM: "The first, ah, half-hour or hour [of the next meeting] to meet and drink and talk about acquisition strategies, and how it all works ..."

By the end of the third meeting, the draft clauses on acquisition, preservation, and protection existed as two separate clauses, one for "Preservation and Protection," and one with the heading, "Acquisition." The references to public and private lands were deleted. The revision was as follows:

Preservation and Protection

Natural areas need preserving and protecting to meet the needs of the present and future. 


\section{Acquisition}

Whenever and wherever possible, natural areas worthy of preservation and protection should be identified and acquired.

Exchanges like those above are typical of the open-ended, practical manifestation of institutional and environmentalist agendas, as they are realized in the local logic of this group's verbal exchanges. The scope rule is on the table, so to speak, not as a non-negotiable decree, but as a persistent and modifiable constraint, one that represents the power of the city to which the PM reorients on a regular basis. This orientation reconstructs the scope rule each time it is invoked, and, as structure-in-action, the committee's deliberations reconstruct the power structures that support the mayor-in-council's pro-development stance. However, at the same time, the PM's vacillations also allow committee members some local decision-making space, affording challenges to the scope rule, such as the clause on "Acquisition." As members repeatedly offer the environmental agenda, the PM repeatedly returns it back to them. Each offer and return recontextualizes both the institutional rule and the proposals for a land acquisition clause. Participants take positions, offer proposals, and convey responses of agreement, disagreement, or dismissiveness. As the PM evaluates, invites responses, and reevaluates, over time and turns of talk his expressions of institutional rules come to co-exist in an ambivalent relationship with accommodations to the environmentalist agenda that amount to subversions of institutional limitations the PM has set in prior interactions. In this way his reformulations of institutional rules incrementally lose ground to the collaboratively negotiated account of the group. Ultimately, this negotiated account becomes the official account in the form of the produced policy statements which include a land acquisition clause.

Conflicting agendas and tensions among participants and their beliefs galvanize decision making through what Cook-Gumperz and Messerman (1999) describe as a productive "regress of ambiguity" (pp. 169-170). These are productive tensions, for, as participants vacillate between doubt or skepticism and agreement, they prolong the process. As Menz (1999) found in his study of negotiated decision-making, "until a solution is settled upon, the oscillation between the two poles ... runs through" a number of "cycles" and occurs in a variety of ways (p. 112). He found that "while one person advocates" for an option, "[an] other person calls this into doubt" (p. 123). In this study, sometimes the vacillation can be seen within one participant (the PM); at other times it occurs between participants. The analysis above shows how the PM's responses afford ambiguity, sometimes supporting and building on other participants' suggestions ("I think it would be best dealt with . . . as a separate item under acquisitions/Pair it up/Yeah"), and at other times reifying management constraints as obstacles ("this is strictly confined to park natural areas, OK?"). Such brokering is like the behaviour Engestrom (1999a) notes in his study of teams wherein one member "repeatedly paraphrased and clarified his point of view, acting as a scaffold to support the formation of an emerging idea" (p. 393). As the PM repeats institutional constraints, recontextualizing them each time, he creates some leeway for disagreement and innovation. When closure appears to be feasible, it is not a result of the assertion of authority alone. Rather, sufficient decision-space has allowed for the incremental development of "sufficient collective weight" (Engestrom, 1999a, p. 401) to support agreement on the written language of the natural areas management policy. At the end of the process members will recognize their interests in the written policy. As ambiguity is created and recreated over exchanges, it diminishes toward agreement, ultimately becoming 
absorbed by "the legitimating power of written text that can be taken as its solution" (CookGumperz \& Messerman, 1999, pp. 169-171). The committee's deliberations thus reconstruct and reify the city's priorities, but with small victories for the members' environmental priorities. Agency, then, is accomplished by committee members as a sequence of multiple, collective, fleeting, tactical discursive actions. On the larger stage, these performances do not appear, their actors relegated to a distal presence at the periphery.

\section{CONCLUSION}

As the findings in this study indicate, as language on land acquisition is reified and recontextualized, it invites further response from participants. Each recontextualization becomes an "object or focus of activity [that] implies an overall direction . . . a provisionally shared purpose or motive" (Russell, 2002, p. 69). The provisional aspect of negotiation activity, however, is silent in the final textual product. The text provides only those traces of participation that Wodak (2000) calls the "transformations" (p. 10) that result from recontextualization. As the analysis has shown, one key transformation is the addition of the land acquisition clause. But this transformation in itself offers little evidence of the tensions of negotiation, the group's conflicts and debates, or their moves towards consensus. In order to make judgments about the authenticity of participation, evidence must be sought elsewhere in the context, specifically in the interactive participatory process that drives and is driven by recontextualization. This study shows how tensions between committee members are evoked in a cooperative effort towards decision-making, how the microdynamics of reification and participation within a learning community can sustain tensions, lead to productive debate, and sometimes result in consensus. Any evidence of participation is otherwise, more or less, elided and is, at best, a matter of speculation.

Returning to the central question of this study, I believe the microanalyses of negotiation talk, conceptualized here as "structure-in-action," provides evidence of how participants interacted in this public decision-making process, evidence that is finer grained and in-themoment than the kinds of evidence textual analysis by itself yields. The analyses provide evidence of participants' active, committed, and ongoing strategizing to satisfy their respective agendas. Microanalyses of talk can therefore give us important information about agency in institutional contexts, information that is additional to what we gain from pursuing evidence of agency as lacunae and traces in the text. Coincident with textual transformations, then, are those transformations in the participatory dimension, where cycles of activity can lead to collaborative revisions in the textual dimension. This additional information may complement or may challenge judgments about the degree of agency that is afforded participants in public processes. In this study, I would argue that the results complement and corroborate the informal consensus among participants that the process was good. The evidence from their decision-making talk and in-the-moment interactions strongly suggests that committee members developed and sustained a reasonable degree of trust and authentic participation. At the very least, this interactive evidence would counter claims of co-optation by institutional forces. The results here suggest that a modest measure of authentic participation and a constrained agency were sustained in the local context of this public decision-making process. 
This study is offered as a contribution to other current research that takes the disciplinary mandates of communications and rhetoric outside the academy and into the public sphere. It is an example of one direction our research might take towards making our disciplines relevant to the goal of meaningful citizen engagement in public processes. By situating textual analysis within the contextual microdynamics of the interactive processes of text production, we can produce useful descriptions of both functional and dysfunctional processes. These descriptions could help create a basis for collaborating with other disciplines to build and test public processes that foster authentic public participation.

\section{REFERENCES}

Agar, M. (1985). Institutional discourse. Text, 5(3), 147-168.

Aune, J.A. (2006). The politics of rhetorical studies: A piacular rite. Quarterly Journal of Speech, 92(1), 69-76.

Bakhtin, M. (1981). The dialogic imagination. M. Holquist (Ed.). Austin: University of Texas Press.

Boden, D. (1994). The business of talk. Cambridge, MA: Polity Press.

Cleaver, F. (2001). Institutions, agency and limitations of participatory approaches to development. In B. Cooke, \& U. Kothari, Participation: The new tyranny? (pp. 3555). New York: Zed Books.

Cook-Gumperz, J., \& Messerman, L. (1999). Local identities and institutional practices: Constructing the record of professional collaboration. In S. Sarangi \& C. Roberts (Eds.), Talk, work and institutional order (pp. 145-181). New York: Mouton de Gruyter.

Daniels, S.E., \& Walker, G.B. (2001). Working through environmental conflict: The collaborative learning approach. Westport, CT: Praeger.

Darcy, M. (2002). Community management: how management discourse killed participation. Critical Quarterly, 44, 32-39.

Depoe, S.P., Delicath, J.W., \& Elsenbeer, M. (Eds.) (2004). Communication and public participation in environmental decision making. Albany: State University of New York Press.

Depoe, S.P., \& Delicath, J.W. (2004). Introduction. In S. P. Depoe, J. W. Delicath, \& M. Elsenbeer (Eds.), Communication and public participation in environmental decision making (pp. 1-12). Albany: State University of New York Press. 
Dias, P., Freedman, A., Medway, P., \& Pare, A. (1999). Worlds apart: Acting and writing in academic and workplace contexts. London: Laurence Erlbaum Associates.

Engestrom, Y. (1999a). Activity theory and individual and social transformation. In Y. Engestrom, R. Miettinen, \& R. Punamaki (Eds.), Perspectives on activity theory (pp. 19-38). Cambridge, UK: Cambridge University Press.

Engestrom, Y. (1999b). Innovative learning in work teams: Analyzing cycles of knowledge creation in practice. In Y. Engestrom, R. Miettinen, \& R. Punamaki (Eds.), Perspectives on activity theory (pp. 377-404). Cambridge, UK: Cambridge University Press.

Engestrom, Y. (1995). Innovative organizational learning in medical and legal settings. In L. Martin, K. Nelson, \& E. Tobach (Eds.), Sociocultural psychology: Theory and practice of doing and knowing (pp. 326-356). Cambridge: Cambridge University Press.

Fairclough, N., \& Wodak, R. (1997). Critical discourse analysis. In T. A. van Dijk (Ed.), Discourse or social interaction. Discourse studies: A multidisciplinary introduction (pp. 258-284). London: Sage Publications.

Giddens, A. (1988). Goffman as a systematic social theorist. In P. Drew \& A. Wootton (Eds.), Erving Goffman: Exploring the interaction order (pp. 250-279). Boston: Northeastern University Press.

Glass, M. (1993). Citizens against the MX: Public languages in the nuclear age. Urbana: University of Illinois.

Goffman, E. (198I). Footing. Forms of talk (pp. 124-159). Philadelphia: University of Pennsylvania Press.

Goffman, E. (1969). Strategic interaction. Strategic interaction (pp. 85-145). Philadelphia: University of Pennsylvania Press.

Halloran, M. (1978). Doing public business in public. In K. K. Campbell \& K. H. Jamieson (Eds.), Form and genre: Shaping rhetorical action (pp. 120-123). Falls Church, VA: The Speech Communication Association.

Herndl, C.G., \& Licona, A.C. (2007). Shifting agency: Agency, kairos, and the possibilities of social action. In M. Zachry \& C. Thralls (Eds.), Communicative practices in workplaces and the professions: Cultural perspectives on the regulation of discourse and organizations (pp. 133-153). Amityville: Baywood Publishing.

Herndl, C.G., \& Brown, S.C. (1996). Introduction. In C. G. Herndl \& S. C. Brown (Eds.), Green culture: Environmental rhetoric in contemporary America (pp. 3-20). Madison: University of Wisconsin. 
Holland, D., \& Lave, J. (2001). History in person: An introduction. In D. Holland \& J. Lave (Eds.), History in person: Enduring struggles, contentious practice, intimate identities (pp. 3-36). Santa Fe: School of American Research Press.

ledema, R. (1999). Formalizing organizational meaning. Discourse and Society, 10(1), 49-65.

Kendon, A. (1988). Goffman's approach to face-to-face interaction. In P. Drew \& A. Wootton (Eds.), Erving Goffman: Exploring the interaction order (pp. 14-40). Boston: Northeastern University Press.

Killingsworth, M. J., \& Palmer, J.S. (1992). Ecospeak: Rhetoric and environmental politics in America. Carbondale: Southern Illinois Press.

Lave, J., \& Wenger, E. (1991). Situated learning. Cambridge: Cambridge University Press.

Leff, M. (2006). Forum: Rhetoric and society in the $21^{\text {st }}$ century. Quarterly Journal of Speech, 92, 51-102.

Mailloux, S. (2006). Places in time: The inns and outhouses of rhetoric. Quarterly Journal of Speech, 92(1), 53-68.

Menz, F. (1999). "Who am I gonna do with this?": Self-organization, ambiguity and decision-making in a business enterprise. Discourse and Society, 1(1), 101-128.

Miller, C. (1994). Rhetorical community: The cultural basis of genre. In A. Freedman \& P. Medway (Eds.), Genre and the new rhetoric (pp. 67-78). London: Taylor \& Francis.

Miller, C. (1993). The polis as rhetorical community. Rhetorica, XI(3), 211-240.

Mumby, D. (1988). Communication and power in organizations: Discourse, ideology, and dominion. Norwood: Ablex Publishing.

Muntigl, P. (2000). The European Union: Policy-making through organizational discursive practices. In P. Muntigl, G. Weiss, \& R. Wodak (Eds.), European Union discourses on un/employment (pp. 1-25). Philadelphia: John Benjamins Publishing.

Natural Areas Management Plan. (2001).

Russell, D. (2002). Looking beyond the interface: Activity theory and distributed learning. In M. Lea \& K. Nicoll (Eds.), Distributed learning (pp. 64-82). New York: Routledge Falmer.

Russell, D. (1997). Rethinking genre in school and society. Written Communication, 14(4), 504-555. 
Sarangi, S., \& Roberts, C. (1999). Introduction: The dynamics of interactional and institutional orders in work-related settings. In S. Sarangi \& C. Roberts (Eds.), Talk, work and institutional order (pp. 1-60). New York: Mouton de Gruyter.

Sarangi, S. (1998). Rethinking recontextualization in professional discourse studies: An epilogue. Text, 18(2), 301-318.

Schneider, B. (2007). Power as interactional accomplishment. In M. Zachary \& C. Thralls (Eds.), The cultural turn: Perspectives on communicative practices in workplaces and the professions (pp. 181-199). Amityville, NY: Baywood Publishing.

Schwarze, S. (2004). Public participation and (failed) legitimation: The case of forest service rhetorics in the Boundary Waters Canoe area. In S. P. Depoe, J. W. Delicath, \& M. Elsenbeer (Eds.), Communication and public participation in environmental decision Making (pp. 137-156). Albany: State University of New York Press.

Senecah, S. (2004). The trinity of voice: The role of practical theory in planning and evaluating the effectiveness of environmental participatory processes. In S. P. Depoe, J. W. Delicath, \& M. Elsenbeer (Eds.), Communication and public participation in environmental decision making (pp. 13-34). Albany: State University of New York Press.

Vygotsky, L. (1978). Mind in society. Cambridge, MA: Harvard University Press.

Walker, G.B. (2004). The roadless areas initiative as national policy: Is public participation an oxymoron? In S. P. Depoe, J. W. Delicath, \& M. Elsenbeer (Eds.), Communication and public participation in environmental decision making (pp. 113-136). Albany: State University of New York Press.

Wenger, E. (1998). Communities of practice. Cambridge, UK: Cambridge University Press.

Williams, B., \& Matheny, A.R. (1995). Democracy, dialogue, and environmental disputes: The contested languages of social regulation. New Haven: Yale University Press.

Wodak, R. (2000). From conflict to consensus? The co-construction of a policy paper. In P. Muntigl, G. Weiss, \& R. Wodak (Eds.), European Union discourses on un/employment (pp. 73-114). Philadelphia: John Benjamins Publishing.

Wodak, R. (1996). Introduction: Orders and disorders. Disorders of discourse (pp. 1-34). London: Longman. 


\section{BIO}

Diana Wegner teaches in the Print Futures Professional Writing Program and Communications Department at Douglas College, New Westminster, BC. She pursues her interest in the analysis and theory of professional, institutional, and marginal discourses. Her articles appear in the Journal of Business and Technical Communication, Rhetor, Technostyle, and edited collections. She has also done consulting work for industry and government. 